\title{
Ferroelectric Electron Emitter having a Vacuum Gap
}

\author{
Iwao Ohwada Member (NGK Insulators, Ltd., ohwada@ngk.co.jp) \\ Tomohiko Sugiyama Non-member (NGK Insulators, Ltd.) \\ Tsutomu Nanataki Non-member (NGK Insulators, Ltd.)
}

Keywords : ferroelectric, electron emission, polarization, vacuum gap, electron charge

We developed the ferroelectric electron emitter which has a unique micro-structure in electron-emitting portion. The electron emitter has the sandwich structure which consists of a lower electrode, a ferroelectric layer and an upper electrode. Fig.1 shows the section view of electron emitting portion. All over the upper electrode, numerous electron emitting micro-holes are distributed in high density. An upper electrode does not entirely adhere to the surface of a ferroelectric layer. There is a vacuum gap between them. The vacuum gap is original feature of a ferroelectric electron emitter which we have developed. We have formed above-described unique micro-structure which has the micro-holes and the vacuum gap only by thick film forming technique. The micro-holes and the vacuum gap are formed automatically in sintering process.

Electron emission process consisits of three steps as follows. The first step is electron charge, the second step is charge retention and the third step is electron emission. Fig. 2 shows the hysteresis characteristics in one cycle of electron emission process.

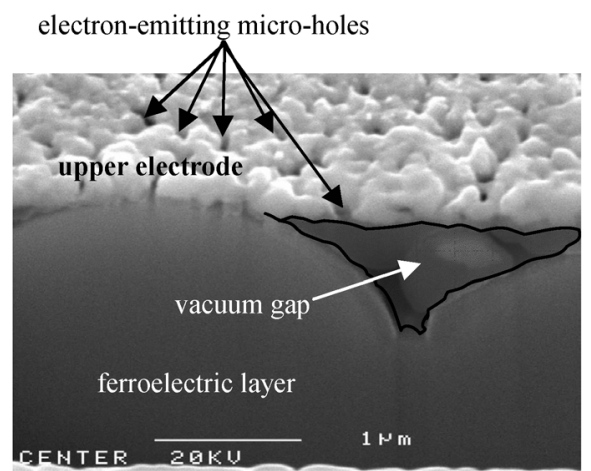

$1 \mu \mathrm{m}$

Fig. 1. Section view of a electron-emitting portion

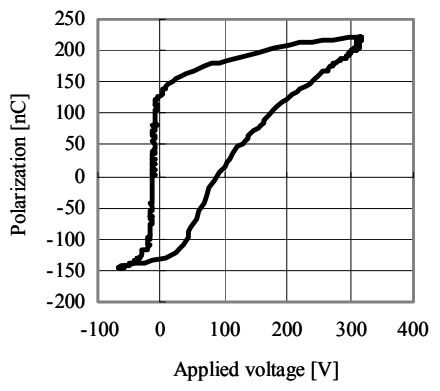

Fig. 2. Hysteresis characteristics in one cycle of electron emission process
The electron emission process has asymmetric property of hysteresis. Based on the asymmetric property and the results of the experiments for each step, we consider the following mechanism of the electron emission process.

At the first step, remnant polarization of the same level as the completely adhered electrode structure is obtained in spite of a vacuum gap. Based on this result, we consider as follows. At the first step, the polarization reversal develops from the point which the upper electrode adheres tightly to the surface of the ferroelectric layer which separates from the upper electrode while the applied voltage increases. In synchronism with the development of the polarization reversal, electrons migrate from the upper electrode to the surface of the ferroelectric layer to neutralize the positive poles of dipoles emerging on the surface of the ferroelectric layer.

The remnant polarization at the second step has the linear relationship with the electron emission amount. Based on this result, we consider that the electron charge is retained by Coulomb attraction of the remnant polarization and electrons are emitted from the electron charge at a certain percentage.

We confirmed the relationship between the electron emission amount and the applied voltage to a vacuum gap at the third stage as shown on Fig.3.

Based on this result, we consider as follows. At the third step, the charged electrons on the surface of the ferroelectric layer are inhibited to migrate to the upper electrode because the negative poles of reversed dipoles emerge at the point which the upper electrode adheres tightly to the surface of the ferroelectric layer before the electrons are released by the polarization reversal on the surface of the ferroelectric layer which separates from the upper electrode. Under this condition, the electrons are expelled by the electric field applied to a vacuum gap above the surface of the ferroelectric layer in process of the polarization reversal. We cnsider that the micro-structure which has the vacuum gap between an upper electrode and the surface of a ferroelectric layer advances the electron emission process (third step).

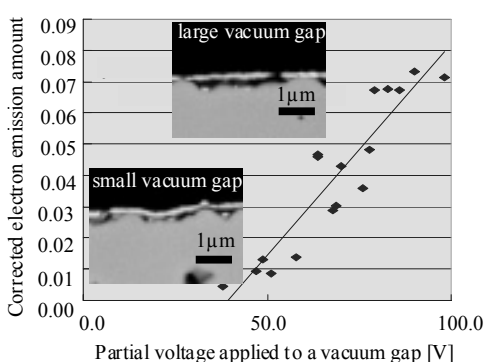

Fig. 3. The corrected electron emission amount as a function of the applied voltage to a vacuum gap 


\title{
真空ギャップを有する強誘電体セラミックス電子放出素子

$\begin{array}{llll}\text { 正員 大和田 } & \text { 嚴* 非会員 杉山 智彦** } \\ \text { 非会員 七㴰 } & \text { 努** }\end{array}$

Ferroelectric Electron Emitter having a Vacuum Gap

Iwao Ohwada*, Member, Tomohiko Sugiyama**, Non-member, Tsutomu Nanataki**, Non-member

\begin{abstract}
A novel electron emitter utilizing the characteristics of ferroelectric ceramic materials has been developed. The electron-emitting portion of the electron emitter has a unique micro-structure which has the vacuum gap between an upper electrode and the surface of a ferroelectric layer. We confirmed electron emission by three-step process which consists of electron charge (the first step), charge retention (the second step) and electron emission (the third step). The ferroelectric hysteresis in the process indicates unique characteristics as follows. At the first step, remnant polarization of the same level as the completely adhered electrode structure is obtained in spite of a vacuum gap because the electron charge develops from the upper electrode to the surface of the ferroelectric layer under the vacuum gap in synchronism with the polarization reversal of the ferroelectric layer. In other hand, at the third step, the electric field in the vacuum gap advances electron emission while the development of the polarization reversal inhibits the return of the electron charge along the surface of the ferroelectric layer.
\end{abstract}

キーワード：強誘電体，電子放出，分極，真空ギャップ，帯電

Keywords : ferroelectric, electron emission, polarization, vacuum gap, electron charge

\section{1. はじめに}

強誘電体セラミックスの分極反転を利用した電子放出素 子は，この 20 年間で多くの研究者によって研究がなされて きた(1) (6)。強誘電体セラミックス電子放出素子の基本構造 は，強誘電体を上部電極と下部電極で挟んだサンドイッチ 構造である。上部電極は例えば節歯状のパターンで形成さ れ，ストライプ電極の間に強誘電体表面を露出させて，電 子放出を行うものである。一方，我々が開発した電子放出 素子は，微細孔を有する上部電極を強誘電体表面と密着さ せずに配置し，その間に真空ギャップを有する構造を特徴 とする。2004 年・2005 年には，この様な特徴を有する電子 放出素子を用いて, 対角 4.3 インチのフィールドエミッショ ンディスプレイを試作し，128 階調の動画像表示を行っ た $^{(7)(8)}$ 。しかしながら，電子放出メカニズムに対する真空ギ ヤップの機能は明確ではなかった。本論文では，本電子放 出素子の電子放出メカニズムを, その過程別に分解し, 各 過程に対して原理実験を実施して検証するとともに，真空

* 日本ガイシ (株) 商品開発センター

干467-8530 名古屋市瑞穂区須田町 2-56

NGK Insulators, Ltd. New Products Development Center

2-56, Suda-cho, Mizuho, Nagoya 467-8530

** 日本ガイシ（株）基盤技術研究所

T467-8530 名古屋市瑞穂区須田町 $2-56$

NGK Insulators, Ltd. Materials Research Laboratory

2-56, Suda-cho, Mizuho, Nagoya 467-8530
ギャップの機能を検証した結果について報告する。

\section{2. 電子放出素子の構造}

我々が開発した電子放出素子の構造を Fig. 1 に示す。電子 放出素子は，下部電極 ・強誘電体層・上部電極からなるサ ンドイッチ構造である。上部電極には一面に微細孔が形成 されており, 直径 $0.01 \mu \mathrm{m} \sim 10 \mu \mathrm{m}$ の微細孔が， $1 \mathrm{~mm}^{2}$ あた り数 100 万個〜数 1000 万個形成されている (Fig. 1(c)参照)。 強誘電体層の表面は, これらの微細孔から露出している。

上部電極は, 強誘電体層に密着しておらず，上部電極下 面と強誘電体層表面の間に真空ギャップが形成されてお り，その距離は最大值で概称 $1 \mu \mathrm{m}$ である (Fig. 2 参照)。

真空ギャップは我々が開発した電子放出素子特有の構造 であり, 上述の微細孔や真空ギャップが, 複雑な薄膜プロ セスを必要とせず，厚膜形成技術のみで形成されることが 大きな特徵である。上部電極ペーストをスクリーン印刷し た後の焼成過程にて, これらの微細孔や真空ギャップが自 動的に形成されるような電極ペース卜・焼成プロセスを開 発したのである。

\section{3. 電子放出実験及びその結果}

〈3·1〉 実験用素子 Fig. 3 に実験用素子の上面図を 示す。ジルコニアセラミックス基板上に，下部電極・強誘 


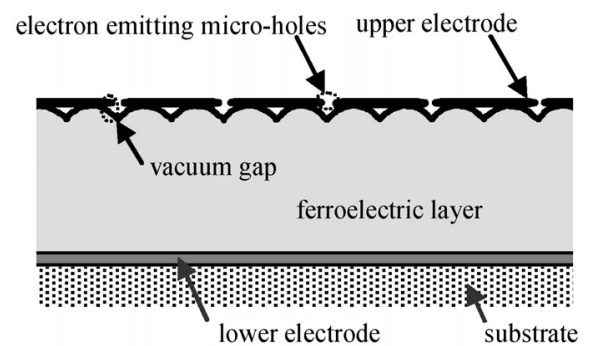

(a) Illustration of cross-section surface upper electrode

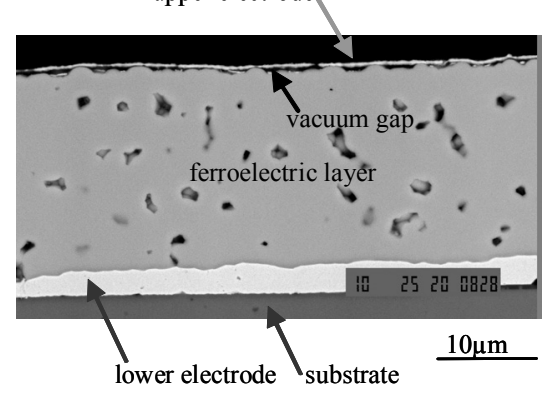

(b) SEM image of cross-section surface

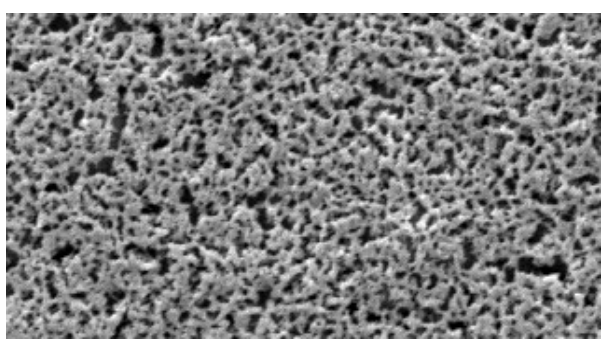

$1 \mu \mathrm{m}$

Black color :electron emitting micro-holes Gray color :upper electrode

(c) Top view of an upper electrode

Fig. 1. Structure of a ferroelectric electron emitter.
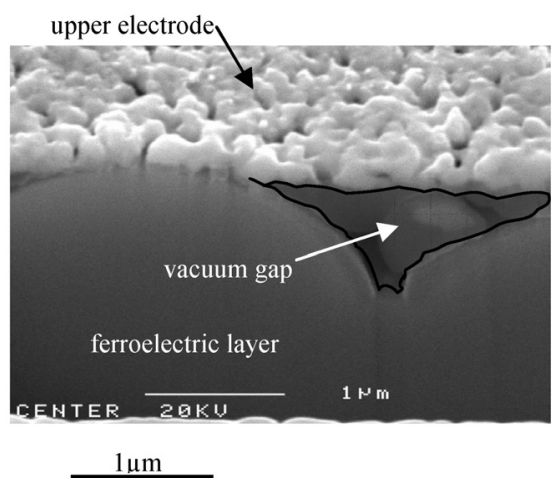

Fig. 2. Section view of a vacuum gap.

電体層・上部電極毎にスクリーン印刷と焼成を繰り返して 素子を形成した。上部電極のサイズは， $0.83 \mathrm{~mm} \times 0.50 \mathrm{~mm}$ で ある。上部電極は，白金に貴金属を微量添加した材料にて 形成される。

Fig. 4 は，実験用素子に用いた強誘電体材料のヒステリシ

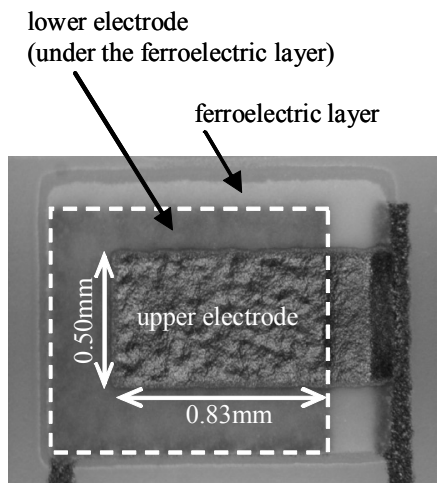

Fig. 3. Top view of a test sample.

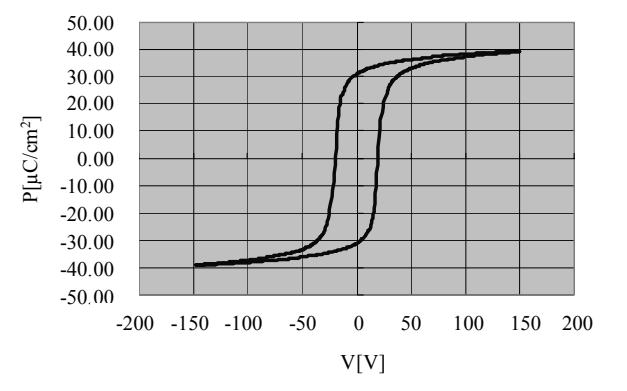

P: Polarization $\left[\mu \mathrm{C} / \mathrm{cm}^{2}\right]$

V: Applied voltage to the ferroelectric layer $20 \mu \mathrm{m}$ thick

Fig. 4. Hysteresis characteristics of ferroelectric material used for a test sample.

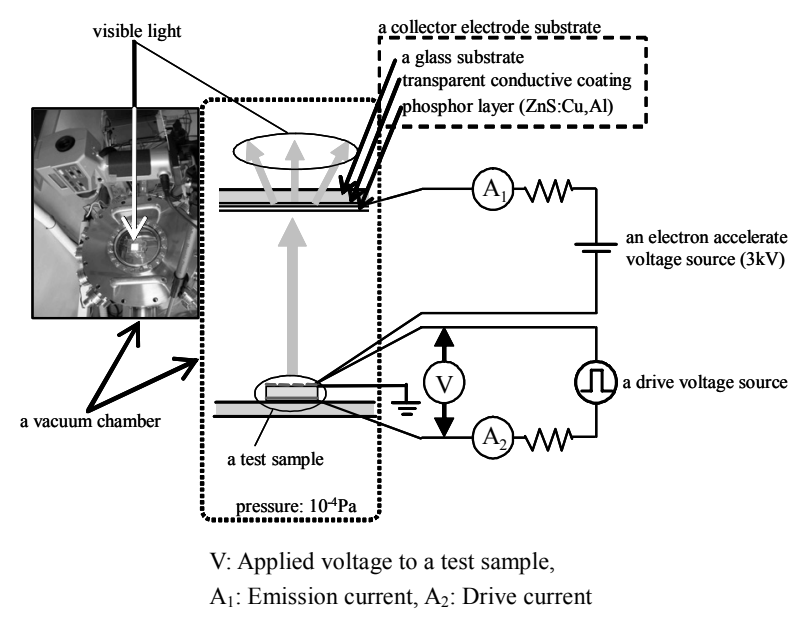

Fig. 5. Experimental setup of electron emission.

ス特性を示す。このヒステリシス特性は, 微細孔や真空ギ ヤップの無い, 強誘電体層に密着した上部電極を有する厚 さ20 $\mu \mathrm{m}$ の強誘電体にて測定した結果である。強誘電体材 料は, $\mathrm{Pb}\left(\mathrm{Mg}_{1 / 3} \mathrm{~N}_{2 / 3}\right) \mathrm{O}_{3}-\mathrm{PbTiO}_{3}-\mathrm{PbZrO}_{3}$ からなる三成分系で, キュリー温度が $150^{\circ} \mathrm{C}$, 厚さ $20 \mu \mathrm{m}$ における抗電圧が $20 \mathrm{~V}$ である。

〈3·2〉 実験内容 Fig. 5 に電子放出実験装置の概要 を示す。圧力 $10^{-4} \mathrm{~Pa}$ の真空チャンバ内に, 実験用素子とコ レクタ電極を Fig. 5 の様に配置する。コレクタ電極は, 透明 電極用 ITO 膜が形成されたガラス基板の電極膜形成面に蛍 


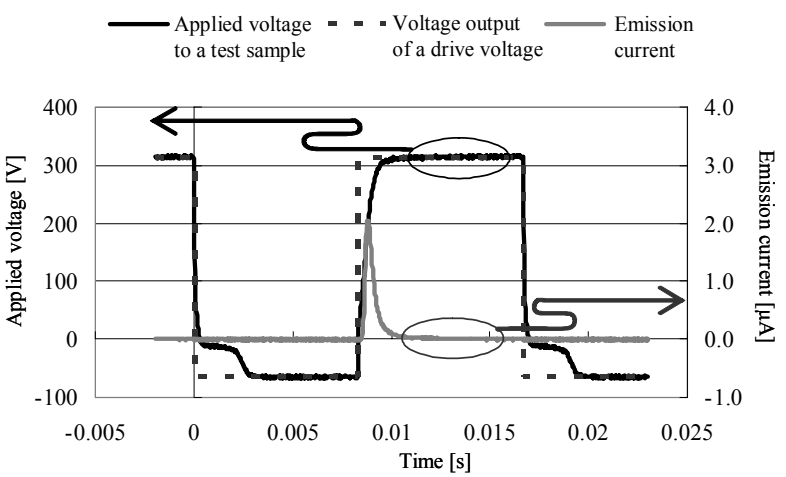

Fig. 6. Applied voltage to a test sample (Fig.5:V) and emission current as a function of time (Fig.5: $\mathrm{A}_{1}$ ).

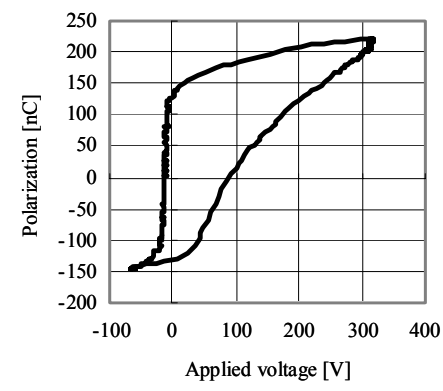

Fig. 7. Hysteresis characteristics in one cycle of electron emission process.

光体 $\mathrm{ZnS}: \mathrm{Cu}, \mathrm{Al}$ 塗布したものである。コレクタ電極は実験 用素子の $5 \mathrm{~mm}$ 上方に配置され, 実験用素子が放出した電子 により, 蛍光体をカソードルミネッセンスで発光させる様 にしている。実験用素子の上部電極は接地されており，実 験用素子の駆動電圧は下部電極から印加した。また，実験 用素子の放出した電子を加速する為の直流高電圧をコレク 夕電極に印加した。図中の記号はそれぞれ，V が実験用素 子への印加電圧， $A_{1}$ がコレクタ電極に流入する実験用素子 からの放出電流， $\mathrm{A}_{2}$ が実験素子の駆動電流を示寸。

$\langle 3 \cdot 3\rangle$ 実験結果 Fig. 6 に印加電圧波形と, 放出電流 波形を示す。ここで，印加電圧波形は，下部電極の電位を 基準とした上部電極の電位で表しており，直列抵抗 $200 \mathrm{k} \Omega$ を介して下部電極に $60 \mathrm{~Hz}$ の矩形波を印加したものである。 1 周期の印加電圧波形は前半部分と後半部分に分けられ, 下 部電極に対して, 前半で $70 \mathrm{~V}$ のパルス電圧, 後半で $-300 \mathrm{~V}$ のパルス電圧を印加した。放出電流波形から電子放出は

-300V を印加した際の立ち上りにて観察され，1 周期分を 積算することで電子放出量が求まる。

印加電圧波形を横軸にとり，駆動電流の積算値から得ら れる分極量を縦軸にとった，実験用素子のヒステリシス特 性を Fig. 7 に示す。尚，電子放出量との比較のため，以降は 分極量を電荷密度ではなく電荷量で示している。この Fig. 7 に示される様に, 印加電圧波形の後半部分では, 前半部分 と比べて分極に要する電圧が大きくなっている。言い換え ると，下部電極を基準にして，上部電極が正極性となる分 極を行う際に要する電圧が大きい非対称のヒステリシス特

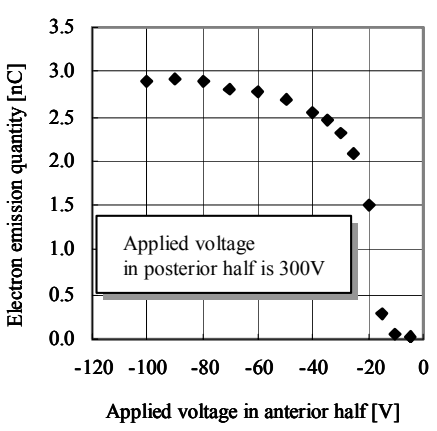

(a)

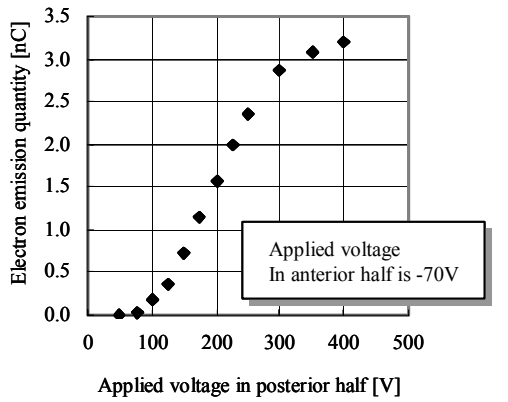

(b)

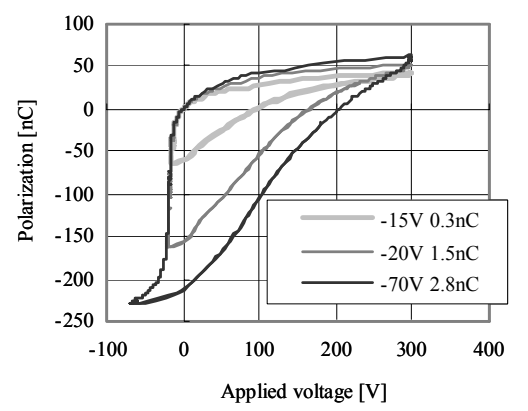

(c)

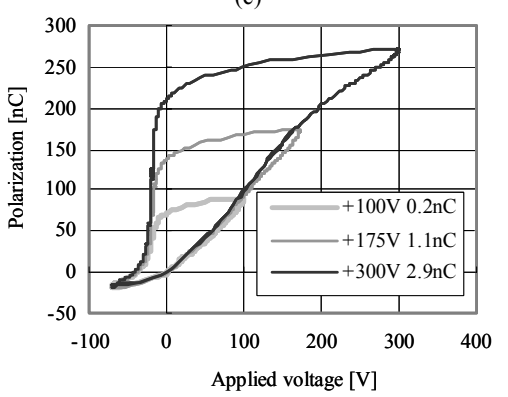

(d)

Fig. 8. Hysteresis characteristics as a function of applied voltage in posterior half.

性を有している。

〈3.4〉駆動電圧に対する電子放出量 Fig. 8(a)に, 印 加電圧の前半部分（上部電極が負極性となる分極を行う） の電圧值に対する電子放出量の関係を示す。また，Fig. 8(b) に, 印加電圧の後半部分（上部電極が正極性となる分極を 行う）の電圧值に対する電子放出量の関係を示す。これら の図から, 電子放出が行われる後半部分の電圧值はもとよ り, 前半部分の電圧值に対しても電子放出量との相関が見 られる。また, Fig. 8(c)及び Fig. 8(d)に, 印加電圧の前半部 


\section{(First step) Electron charge}

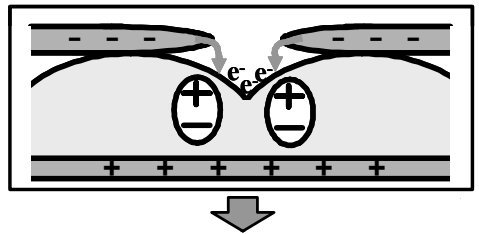

(Second step) Charge retention

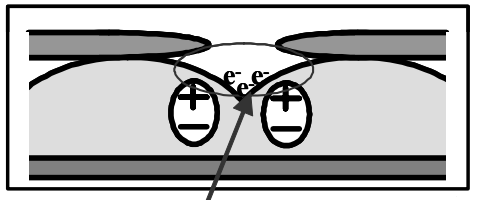

electrons on the surface of a ferroelectric layer

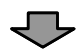

(Third step) Electron emission

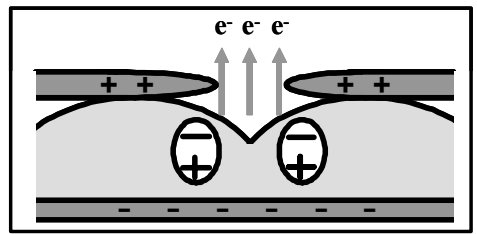

Fig. 9. Electron emission process of ferroelectric electron emitter.

分もしくは後半部分の電圧值をパラメータとしたヒステリ シス特性を示す。印加電圧による分極量の変化を分かりや すくするため, ヒステリシス特性の縦軸は印加電圧 $0 \mathrm{~V}$ にお ける位置で揃えた。この図から，両極性の分極量と電子放 出量の相関が見られる。

\section{4. 電子放出に対する仮説}

Fig. 7 及び Fig. 8 の実験結果を踏まえて，我々は，電子放 出過程について仮説を設定した (Fig. 9 参照)。電子放出は, 強誘電体の分極が 1 回転 $\left(180^{\circ}\right.$ の分極反転が 2 回) するサ イクルで行われ，この 1 サイクルは，帯電過程 (第 1 段階), 帯電保持過程（第 2 段階）, 放出過程（第 3 段階）の 3 段階 に分解される。次章から，各過程別に電子放出機構を検証 する原理実験結果と，真空ギャップの機能に関する考察を 述べる。

\section{5. 帯電過程（第 1 段階）}

第 1 段階では, 下部電極の電位を基準として上部電極に 負極性電圧を印加することにより，双極子の正極側が強誘 電体表面近傍に現れる様に分極反転を行う。この第 1 段階 では，強誘電体表面の帯電メカニズムを解明する為に，以 下の実験を行った。

〈5·1〉ヒステリシス特性Ｆig. 10 は，真空ギャップ を有する実験用素子と, 真空ギャップの無い上部電極を有 する，実験用素子と同サイズ・同材料の強誘電体素子につ いて，ヒステリシス特性を比較して示したものである。Fig. 10 において，印加電圧が負極性の領域が第 1 段階に相当す

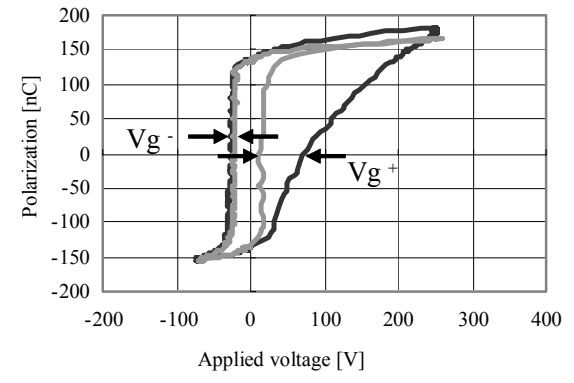

- a ferroelectric electron emitter having a vacuum gap a ferroelectric element not having a vacuum gap

Fig. 10. Hysteresis characteristics of a ferroelectric electron emitter having a vacuum gap and a ferroelectric element not having a vacuum gap.

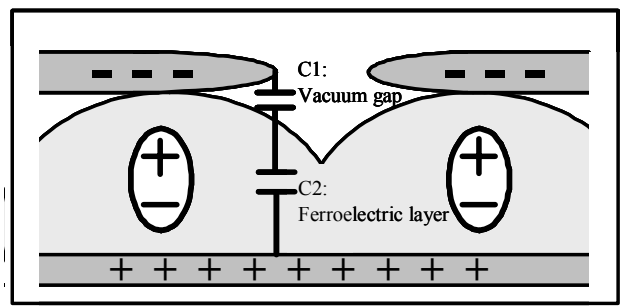

Fig. 11. Equivalent circuit model of a ferroelectric electron emitter having a vacuum gap.

る。この領域におけるヒステリシス特性が上部電極の構造 に関わらず, ほぼ一致していることから，真空ギャップの 有無によらず同程度の印加電圧で同程度の分極が進行する ことが示されている。従って, 真空ギャップを有する電極 構造においても, 上部電極が密着していない強誘電体表面 は分極されていると考えられる。

ここで, Fig. 11 に示す様な等価回路にて，上下電極間の 印加電圧に対する真空ギャップへの分圧を考察する。Fig. 11 において, 真空ギャップ部分をキャパシタ $\mathrm{C} 1$ (比誘電率 1, 厚さ $0.1 \mu \mathrm{m}$ ), 強誘電体層をキャパシタ $\mathrm{C} 2$ (比誘電率 5000 , 厚さ $20 \mu \mathrm{m})$ とすると, 単位面積あたりで静電容量を比較 した場合, $\mathrm{C} 2$ は $\mathrm{C} 1$ の 25 倍となるので, 真空ギャップへの 分圧が大きく現れる計算となる。しかし, Fig. 10 の $\mathrm{Vg}^{-}$で 示したように真空ギャップへの分圧はほとんど０であり， 上部電極が密着していない強誘電体表面では, 分極の進行 に伴って双極子の正極側を電気的に中和する帯電（電子の 付着）も進行し，上部電極とほぼ同電位となっていると考 えられる。

〈5·2〉大気中における第 1 段階のふるまい ここで 1 周期の印加電圧を, (1)第 1 段階のパルス電圧, (2)第 2 段階 の $0 \mathrm{~V}$ 直流電圧, (3)第 3 段階のパルス電圧, の 3 段階に分割 して，(1)と(2)からなる波形と，(2)と(3)からなる波形を，個 別に素子に印加する（Fig. 12 参照）ことで以下の実験を行 った。このように印加電圧を分割することに対する予備検 討として, (2)の段階にあたる $0 \mathrm{~V}$ 直流電圧の印加時間が 1 時 


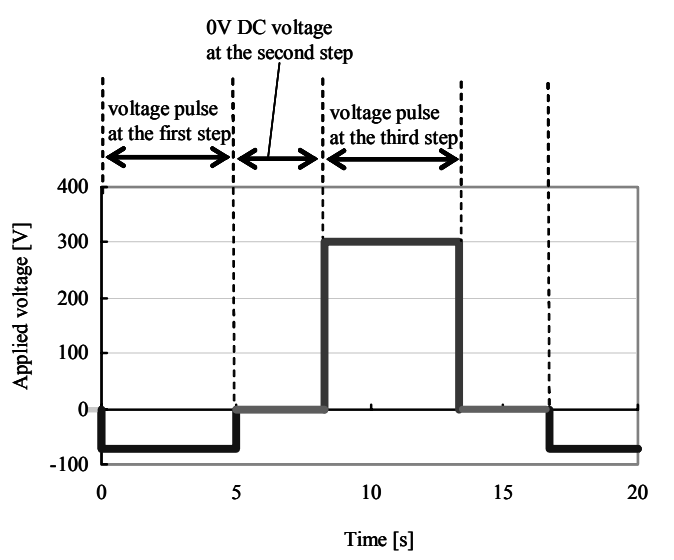

Fig. 12. Separation of an applied voltage to three elements.

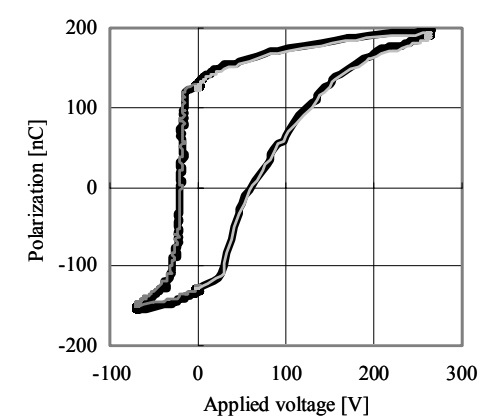

$$
\begin{aligned}
& \text { Applying voltages of all steps in vacuum } \\
& \text { Applying voltage at the first and second steps in the air } \\
& \text { Applying voltage at the second and third steps in vacuum }
\end{aligned}
$$

Fig. 13. Hysteresis characteristics of a ferroelectric electron emitter applied pulse voltage at the first step in the air and the one applied same voltage in vacuum.

間の場合と，(2)の段階が皆無の場合（1)のパルス電圧の直 後から(3)のパルス電圧を印加) で, 電子放出量を比較した。 その結果，同量の電子放出量が確認されたことから，上記 の様な印加波形の分割によって, 電子放出に支障を来すこ となく電子放出特性の調査が可能であることを確認した。

\section{$\langle 5 \cdot 2 \cdot 1\rangle$ 実験内容 (1) と(2)からなる電圧波形を大気} 中で印加した後，(2)の $0 \mathrm{~V}$ 直流電圧印加時に周囲環境を $10^{-4} \mathrm{~Pa}$ まで減圧し，真空中にて(2) と(3)からなる電圧波形を 印加して電子放出量を測定した。

$\langle 5 \cdot 2 \cdot 2\rangle$ 実験結果 上記実験内容の (1)から (3)までに 対応するヒステリシス特性は， $10^{-4} \mathrm{~Pa}$ の真空中にて(1)から (3)までを実施した場合と，ほぼ一致する（Fig. 13 参照）。ま た，電子放出量も， $10^{-4} \mathrm{~Pa}$ の真空中にて(1)から (3)までを実 施した場合の $80 \%$ が得られた。

$\langle 5 \cdot 2 \cdot 3\rangle$ 考察 上記実験結果を踏まえて, 強誘電体 表面の帯電入カニズムを考察した。帯電メカニズムの可能 性として，以下の 3 つの仮説を設定した (Fig. 14 参照)。

第 1 の仮説は，上部電極と強誘電体が鋭角に接触した電 界集中箇所からのフィールドエミッションである。この場 合, 帯電電子の供給源は上部電極と考えている。第 2 の仮
Possibility 1) Field Emission?

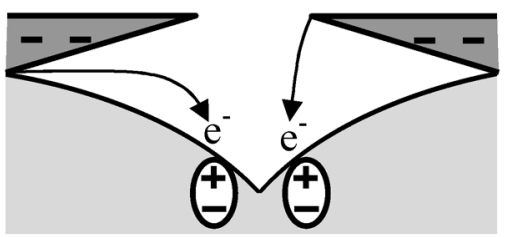

Possibility 2) Charge of the suspended electrons in vacuum atmosphere?

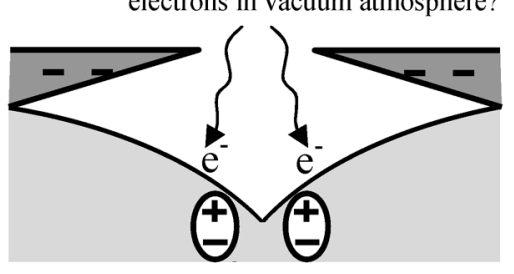

Possibility 3) Charge of migrating electrons on the surface of the ferroelectric layer?

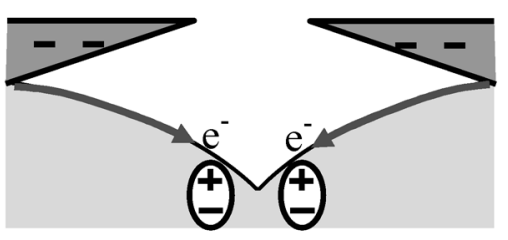

Fig. 14. Three possibilities for the mechanism of the electron charge.

説は，真空中雾囲気を浮遊する電子の付着である。第 3 の 仮説は, 強誘電体の表面に沿った電子の移動である。この 場合の電子の供給源も上部電極と考えている。 $\langle 5 \cdot 1\rangle$ 節で 述べた様に，上下電極間の印加電圧に対する真空ギャップ への分圧はほとんど 0 であったことから, 第 1 の仮説にあ るフィールドエミッションを発現する電界集中が存在する とは考えにくい。更に, $\langle 5 \cdot 2 \cdot 2\rangle$ 節の実験結果から大気中 でも真空中と同様に帯電が起こると考えられるが, 大気圧 の平均自由行程では Fig. 2 のような $1 \mu \mathrm{m}$ 程度の距離を電子 が浮遊するとは考えにくい。更に, $10^{-6} \mathrm{~Pa}$ の高真空環境に おいても $\langle 5 \cdot 2 \cdot 2\rangle$ 節で示した結果と同様のヒステリシス特 性が得られている。従って, 第 1 の仮説であるフィールド エミッションと, 第 2 の仮説である真空中雰囲気を浮遊す る電子の付着は, 周囲環境に大きく左右されると考えられ る為，これらの仮説を採択できない結果である。

これらの結果を踏まえると, 第 3 の仮説である強誘電体 表面の電子の移動が, 第 1 段階における強誘電体表面の帯 電メカニズムとして最も妥当であると考えられる。従って, この第 1 段階においては, 真空ギャップを有する上部電極 構造が強誘電体表面の帯電に寄与しているとは言えない。

\section{6. 帯電保持過程（第 2 段階）}

第 1 段階の後, 第 2 段階では $0 \mathrm{~V}$ 直流電圧に対して強誘電 体の残留分極が現れる。〈5·2〉節の予備検討で示した様に, 強誘電体表面の帯電保持能力は高く, 残留分極の双極子が 
強誘電体表面の帯電電子に対してクーロン引力を及ぼして いると考えられる。この章では，第２段階における残留分 極量と電子放出量との関係を示す。

$\langle 6 \cdot 1\rangle$ 実験内容 ここでも，〈5·2〉節同様， 1 周期の 印加電圧を(1)・(2)・(3)の 3 段階に分割した。周囲の圧力条 件は， $10^{-4} \mathrm{~Pa}$ で固定した。先ず(1)と(2)からなる電圧波形を 周囲温度 $25^{\circ} \mathrm{C}$ 環境下で印加した後，第 2 段階に相当する (2)の $0 \mathrm{~V}$ 直流電圧印加状態にて, 素子を恒温槽に入れて種々 の温度まで加熱した。その後, 周囲温度を $25^{\circ} \mathrm{C}$ 戻し, (2) と (3)からなる電圧波形を印加した。ここで, 素子を構成す る強誘電体層のキュリー温度は $150^{\circ} \mathrm{C}$ である。

$\langle 6 \cdot 2\rangle$ 実験結果 Fig. 15 に，第 2 段階における周囲 温度に対するヒステリシス特性の変化の様子を示す。ここ で, 印加電圧 $0 \mathrm{~V}$ における分極量の分極反転による変化分を 残留分極量とする。残留分極量の変化を分かりやすくする ため, ヒステリシス特性の縦軸は印加電圧 $0 \mathrm{~V}$ のプラス側で 揃えた。残留分極量は周囲温度が高くなるに従って減少し た。残留分極量と電子放出量の関係を調べると, Fig. 16 の ように線形な相関関係を有することが確認された。この結 果から, 強誘電体表面の帯電量は, 残留分極量に相当する 量が存在し, その帯電量に対して, 一定の駆動条件で決定 される一定の割合にて電子放出量が得られていると考えら れる。従って，この第 2 段階における帯電保持量は，強誘 電体層の残留分極量で決定され, 真空ギャップを有する上 部電極構造が寄与しているとは言えない。

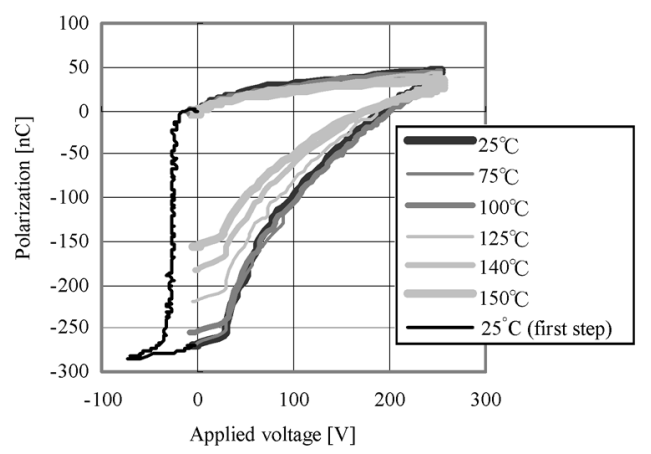

Fig. 15. The hysteresis characteristics as a function of the ambient temperature at the second step.

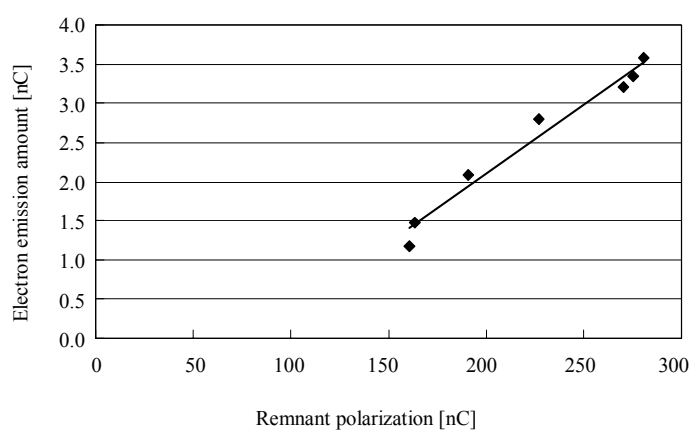

Fig. 16. The electron emission amount as a function of the remnant polarization.

\section{7. 放出過程（第 3 段階）}

Fig. 10 において, 印加電圧が正極性の領域が第 3 段階に 相当する。このヒステリシス特性より, 第 3 段階は, 第 1 段階と比較して分極反転に必要な印加電圧が大きい。また, この領域では, 同一分極量を得るのに必要な印加電圧が, 真空ギャップの無い素子と比べて, 真空ギャップを有する 実験用素子の方が大きいことが分かる。ここで再度, Fig. 11 に示す様な等価回路にて, 上下電極間の印加電圧に対する 真空ギャップへの分圧を考察する。同一分極量に対する強 誘電体層への印加電圧は, 真空ギャップの有無によらない と考えられる。従って, 真空ギャップを有する実験用素子 の印加電圧と, 真空ギャップの無い素子の印加電圧との電 圧差（Fig. 10 における $\mathrm{Vg}^{+}$) が, キャパシタ $\mathrm{C} 1$ で表される 真空ギャップへの分圧であると考えられる。我々は, 以下 の実験にて, 真空ギャップへの分圧（以下，真空ギャップ 電圧）と電子放出量との関係を検証した。

$\langle 7 \cdot 1\rangle$ 実験内容( 1 ) 上部電極材料の微調整と, 上部 電極の焼成プロセス制御により，異なる真空ギャップを有 する 17 個の実験用素子を作成した。ここで, これら 17 個 の実験用素子は, いずれも〈3・1〉節で示した材料の強誘電 体を用いている。これらを $10^{-4} \mathrm{~Pa}, 25^{\circ} \mathrm{C}$ 周囲環境で固定 して駆動し, 真空ギャップ電圧と電子放出量を測定した。

$\langle 7 \cdot 2\rangle$ 実験結果(1) 上記の周囲環境下で, Fig. 6 で 示した周波数 $60 \mathrm{~Hz}$ の駆動波形を印加して, 1 周期の駆動波 形あたりの電子放出量を測定した。電子放出量を決定する パラメータとしては，ここで対象とする真空ギャップ電圧 以外に, 上部電極に形成された微細孔（電子放出孔として 機能する）の開口率 $\mathrm{A}_{\mathrm{h}}$ 及び，〈6・2 $\langle$ 節で示した残留分極量 $\mathrm{P}_{\mathrm{r}}$ が挙げられ, いずれも線形な相関関係であることが確かめ られた。電子放出量と真空ギャップ電圧との関係を明確に する為に, 電子放出量の実測值 $\mathrm{Q}_{\mathrm{me}}$ をもとに( 1 )式にて補正 電子放出量 $\mathrm{Q}_{\mathrm{ce}}$ を算出した。

$$
\mathrm{Q}_{\mathrm{ce}}=\mathrm{Q}_{\mathrm{me}} /\left(\mathrm{A}_{\mathrm{h}} \times \mathrm{P}_{\mathrm{r}}\right)
$$

真空ギャップの異なる 17 個の実験用素子について, 上部 電極の SEM 観察像を画像処理することにより, 微細孔の開 口率を算出するとともに, 素子の駆動により, 電子放出量 とヒステリシス特性（これにより残留分極量と真空ギャッ プ電圧が得られる）を測定した。この結果をもとに, 真空 ギャップ電圧に対する補正電子放出量の関係を Fig. 17 に示 す。ここでプロットした真空ギャップ電圧は, 分極量が 0 のときの值である。これより, 電子放出量は真空ギャップ 電圧と強い相関関係があることが分かる。この段階で放出 過程のメカニズムを特定することは出来ないが, 強誘電体 表面が分極反転する際に，双極子が及ぼしていたクーロン 引力から開放された帯電電子が, 強誘電体表面に沿って移 動せずに真空中へ放出する様に, 真空ギャップに印加され た電界が機能している, と我々は考えている。本節の実験 結果から, この第 3 段階における電子放出量に対して, 真 空ギャップを有する上部電極構造が寄与していると言え 


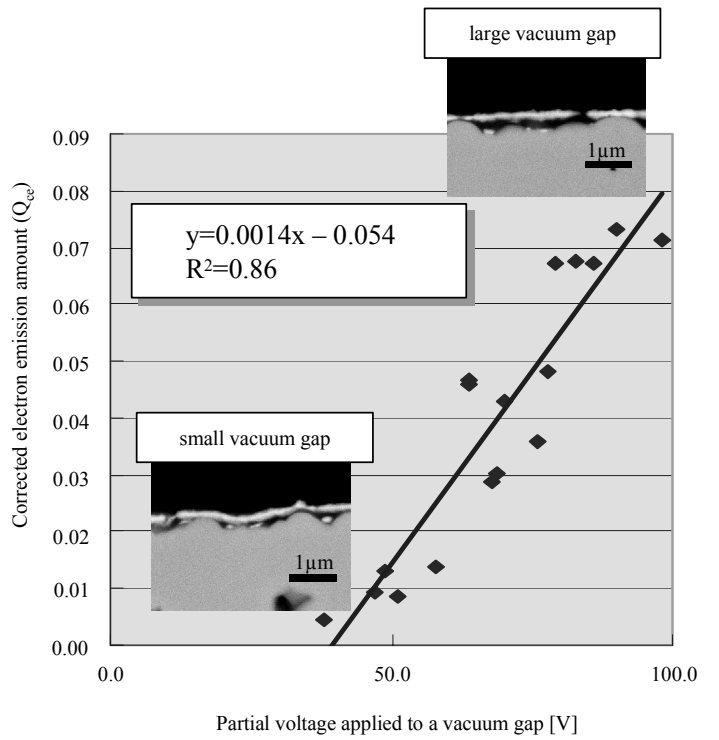

Data from 17 samples which have
>same ferroelectric material
>different vacuum gaps

Fig. 17. The corrected electron emission amount as a function of the partial voltage applied to a vacuum gap.

る。

$\langle 7 \cdot 3\rangle$ 実験内容 $(2)$ 上記考察を別の観点から検証 するべく, 放出電子のエネルギー分布を測定した。上記考 察の如く真空ギャップの印加電界が機能すれば, Fig. 5 で示 した様な, コレクタ電極に印加する加速電圧（以下，コレ クタ電圧）が０でも電子放出量が得られるはずである。そ こで, Fig. 5 に示した実験装置にて, コレクタ電圧をー500[V] から 3000[V]まで変化させて, コレクタ電極に到達する電子 放出量を測定した。ここで，コレクタ電圧が負の場合は, 電子放出を妨げる外部電界を印加するということであり, この場合にコレクタ電極に到達する電子は, 放出エネルギ 一を有する電子ということになる。

〈7·4〉実験結果(2) Fig. 18 に放出エネルギー測定 に用いた実験用素子の駆動電圧に対するヒステリシス特性 を示す。

Fig. 18 の駆動条件を固定させて, コレクタ電圧を一 $500[\mathrm{~V}]$ から 3000[V]まで変化させ, そのコレクタ電圧にて測定され た電子放出量を Fig. 19(a)に示す。また，Fig. 19(b)には，コ レクタ電圧範囲別に電子放出量を示した。コレクタ電圧 $3000[\mathrm{~V}]$ での電子放出量 $1.64[\mathrm{nC}$ の $52 \%$ に相当する $0.86[\mathrm{nC}]$ が, $0 \mathrm{~V}$ のコレクタ電圧に対してもコレクタ電極に到達した。 更に, コレクタ電極に電子の到達を確認したコレクタ電圧 值の最小值 (負の值で最大の絶対值) はー150[V]であり, Fig. 18 をもとに想定され得る真空ギャップ電圧と適合する。こ の結果から, 強誘電体層表面に現れた双極子からのクーロ ン力から開放された帯電電子が, 真空ギャップ電圧で加速 されていると考えることが出来る。

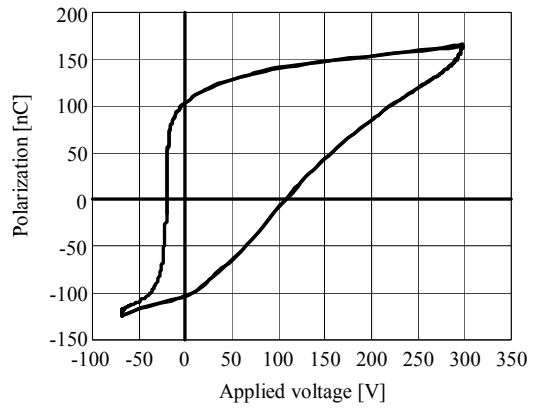

Fig. 18. The hysteresis characteristics of the test sample to measure the electron energy.

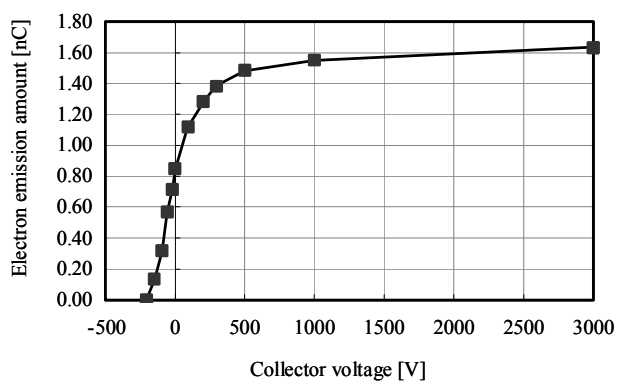

(a) The electron emission amount as a function of the collector voltage

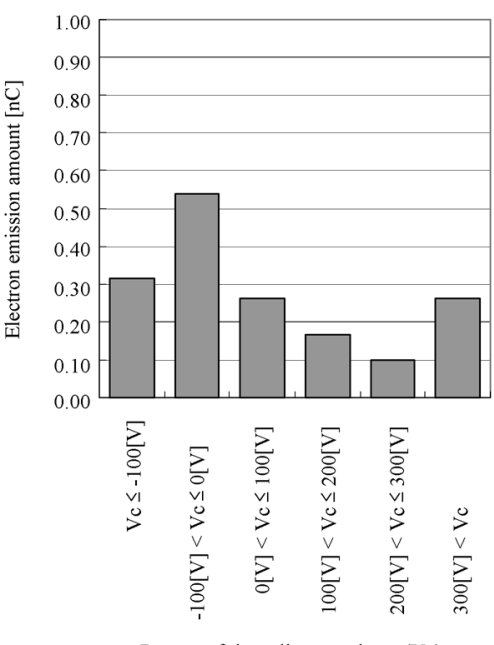

(b) The electron emission amount classified by the ranges of the collector voltage $(\mathrm{Vc})$

Fig. 19. The electron emission amount as a function of the collector voltage.

\section{8. 結び}

我々は，上部電極と強誘電体表面の間に真空ギャップを 有する構造の強誘電体セラミックス電子放出素子を開発し た。1 サイクルの電子放出過程は, 印加電圧の極性に対して 非対称なヒステリシス特性を示し, 我々はこれを, 帯電過 程 (第 1 段階), 帯電保持過程 (第 2 段階), 放出過程（第 3 段階) の 3 段階に分解し, 電子放出機構の検証を行った。

検証実験から得られた結果は以下の通りである。(1)第 1 段階では, 強誘電体層の分極反転の進行と同時に, 強誘電 


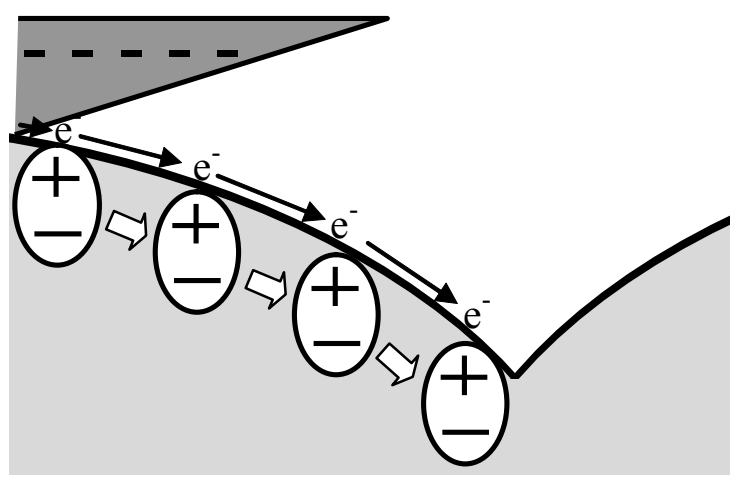

(a) The first step

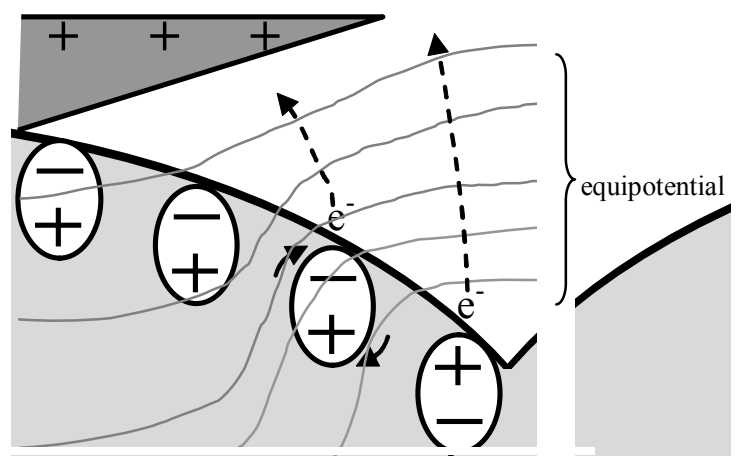

(b) The third step

Fig. 20. The hypothesis about the mechanism.

体の表面の帯電が進行する。(2)第 2 段階における残留分極 量が電子放出量に寄与寸るパラメータである。(3)第 3 段階 における真空ギャップ電圧が電子放出量に寄与するパラメ ータである。

上記の結果をもとに考えられる第 1 段階及び第 3 段階の メカニズムを Fig. 20(a), Fig. 20(b)に示す。

第 1 段階では, 印加電圧の増加に従って, 強誘電体表面 の分極反転は，上部電極が密着した箇所から，上部電極が 離隔した箇所へと進行する。これと同時に，強誘電体表面 に現れた双極子の正極を中和するべく，上部電極から強誘 電体表面に沿った電子の移動が行われ，強誘電体表面の带 電が進行すると考えられる。つまり，強誘電体の表面に沿 った分極反転の進行方向と電子の移動の方向が一致してい ると言える。一方，第 3 段階では，上部電極が密着した強 誘電体表面の分極反転が完了して，双極子の負極が強誘電 体の表面に現れた後に，上部電極が離隔した箇所の分極反 転が行われる。従って，上部電極が離隔した箇所で双極子 からのクーロン引力から開放された帯電電子は，強誘電体 表面に沿った移動を妨げられる。ここで，真空ギャップに 印加された電界が帯電電子を真空空間へ放出する様に機能 すると考えられる。つまり，この場合，強誘電体の表面に 沿った分極反転の進行方向と, 電子の移動の方向が一致し ていないと言える。以上から，真空ギャップを有する強誘 電体セラミックス電子放出素子の電子放出サイクルにおけ るヒステリシス特性の非対称性は, 強誘電体表面に沿った 分極反転の進行方向と, 強誘電体表面に沿った電子の移動
方向から説明され，これらの方向が一致しない過程で真空 空間へ電子を導く様な電界を生成する機能を真空ギャップ が有していると考えられる。

(平成 18 年 12 月 14 日受付, 平成 19 年 9 月 5 日再受付)

\section{文献}

(1) H. Gundel, H. Riege, E. J. N. Wilson, J. Handerek, and K. Zioutas : "Copious electron emission from PLZT ceramics with a high zirconium concentration", Ferroelectrics, Vol.100, p.1 (1989)

(2) V. F. Puchkarev and G. A. Mesyats : "On the mechanism of emission from the ferroelectric ceramic cathode", J. Appl. Phys., Vol.78, p.5633 (1995)

(3) D. Shur, G. Rosenman, and Ya. E. Krasik : "Surface discharge", Ferroelectrics, Vol.100, p.1 (1989)

(4) M. Miyake, K. Suzuki, K. Yasuoka, and S. Ishi : "Electron Emission from Ferroelectric Cathodes Excited by Pulse Voltage", T. IEE Japan, Vol.119-A, No.5, p.622 (1999-5) (in Japanese)

三宅賢稔・鈴木賢司・安岡康一・石井彰三 : 「パルス電界印加による 強誘電体陰極からの電子放出機構」, 電学論 A., 119, 5, p.622 (1999-5)

(5) G. Rosenman and D. Shur : "Electron emission from ferroelectrics", $J$. Appl. Phys., Vol.88, p.6109 (2000)

(6) K. Omura and S. Morita : "Electron emission from Polyvinylidenefluoride Ferroelectric Substance by Polarization Inversion", Jpn. J. Appl. Phys., Vol.43, p.689 (2004)

(7) Y. Takeuchi, T. Nanataki, and I. Ohwada : "Novel Display Panel Utilizing Field Effect - Ferroelectric Electron Emitters", IDW'04, p.1193 (2004)

(8) Y. Takeuchi, T. Nanataki, and I. Ohwada : "Novel Device Structure of Field Effect - Ferroelectric Electron Emitter", SID Int. Symp. Dig. Tech. Pap., p.1724 (2005)

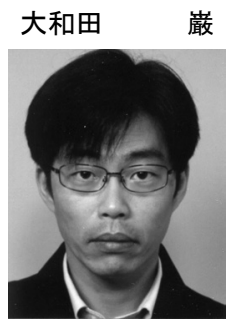

（正員） 1965 年 12 月 25 日生。 1990 年 3 月名 古屋大学大学院修士課程修了。同年日本ガイシ （株）入社。現在, 同社商品開発センターマネ ージャー。
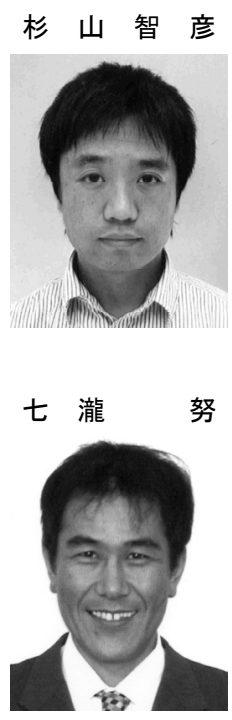

(非会員) 1977 年 9 月 28 日生。2002 年 3 月名 古屋大学大学院修士課程修了。同年日本ガイシ (株) 入社。現在，同社基盤技術研究所研究員。
員） 1961 年 8 月 11 日生。 1986 年 3 月静 岡大学大学院修士課程修了。同年日本ガイシ （株）入社。現在，同社基盤技術研究所グルー プマネージャー。 